\title{
Trade of China and India with Africa after the 2008 Financial Crisis
}

\author{
WIOLETTA NOWAK ${ }^{*}$
}

ABSTRACT The paper analyses the trade competition between China and India in Africa over the period from 2008 to 2017. After the 2008 financial crisis, China increased its advantage over India in exports of goods to rich African countries and in imports of goods from resource-abundant Africa's least developed countries. China-Africa and India-Africa trade relations are win-win relations. However, African countries are becoming more and more dependent on the condition of the Chinese economy. Compared to Chinese exports, Indian ones destroy fewer African markets.

ince the beginning of the $21^{\text {st }}$ century, China and India have been intensively developing their trade relations with African countries. Both China-Africa and India-Africa trade relations are winwin relations. However, Sino-Africa trade relations have recently become win-lose relations in favor of China. For China, Africa has steadily become more of an export than an import market. Besides, the expansion of Chinese goods causes the displacement of African products from local markets. Moreover, China has substantially increased its importance as a source of imports for African countries. Several countries in Africa are dependent to China on trade. In contrast to China, India recorded a negative trade balance in merchandise trade with Africa in the years 2008-2017. Compared to Chinese exports, Indian ones destroy fewer African markets. India exports to Africa not only final goods but also components of production. China always dominated over India in merchandise trade with Africa. However, after the 2008 financial crisis, it managed to increase its advantage over India in exports of goods to rich African countries and in imports of goods from resource-abundant Africa's least developed countries. The aim of the paper is to show the trade competition between China and India in Africa over the period from
* University of Wroclaw, Poland

Insight Turkey Vol. 21 / No. 1 / 2019, pp. 41-51 


\section{Generally, competitive}

political advantage, economic

diplomacy, and development

assistance have been the

building blocks of China-

Africa trade and economic

cooperation in the $21^{\text {st }}$

century
$\mathrm{CAC)}$ at the ministerial conference in Beijing. During the $2^{\text {nd }}$ Ministerial Conference of FOCAC held in 2003, China declared a further increase in development assistance for Africa and zero-tariff treatment to products exported by some African LDCs to China. It also began to build special economic zones in Africa to develop infrastructure, improve customs procedures, and overcome obstacles to investment. ${ }^{1}$ In 2006 , on the $50^{\text {th }}$ anniversary of establishing formal Sino-African diplomatic ties, China decided to develop a new type of strategic partnership with Africa featuring political equality and mutual trust, win-win economic cooperation and cultural exchange. What's more, the China-Africa Development Fund was set up. At the end of 2006, Chinese leaders announced that the Export-Import Bank of China would provide $\$ 2$ billion in concessional loans and $\$ 3$ billion in preferential export credits to African countries over the period from 2007 to 2009. In the years that followed, China has systematically increased its assistance to Africa. During the Ministerial Conferences of FOCAC in 2009 and 2013, China declared it would provide $\$ 10$ billion in preferential credits to Africa in the years 2010-2012 and a $\$ 20$ billion line of credit from 2013 to $2015 .^{2}$ The main outcome of the $6^{\text {th }}$ Ministerial Conference of FOCAC in 2015 was China's declaration of further assistance in the amount of $\$ 60$ billion for African countries in the years 2016-2018.

In 2010, China implemented a duty-free, quota-free (DFQF) market 


\section{Africa is a more strategic} trading partner for India than it is for China as it accounted for 8.1 percent of India's trade with the world in 2017, while only 4.2 percent of China's total trade can countries. In the 2000s, India extended lines of credit and grants for Africa. Since 2004, it has supported African countries under the Indian Development and Economic Assistance Scheme. India also committed $\$ 5.4$ billion to Africa at the First India-Africa Forum summit and \$5 billion at the second summit. During the third summit, India declared it would provide a further $\$ 10$ billion in concessional loans and $\$ 600$ million in grants to African countries.

dia's total tariff lines. The remaining 1.8 percent of the tariff lines were retained in the Exclusion List. In 2015, the DFTP scheme was further expanded and simplified. Since then, to enjoy tariff preference under the DFTP the product should be wholly produced or obtained in the LDC or should meet the requirement of a change in sub-heading and 30 percent of local value added. ${ }^{6}$

As of October 2017, 26 of Africa's LDCs have been designated as beneficiaries to the DFTP scheme. ${ }^{7}$ The DFTP scheme includes several key export products of African LDCs, such as cocoa, cotton, copper ores, cane sugar, fish fillets, readymade garments, and non-industrial diamonds. At the same time, it excludes a number of products of export interest to Africa's LDCs, such as coffee, tea, cashew nuts, some milk products, cream (with sugar), whole milk powder, wheat flour, spices, oilseeds, wine and spirits, beer, tobacco, and cigarettes. $^{8}$

India, like China, uses foreign aid to develop its trade relations with Afri-
In 2018 during his visit to Uganda, Prime Minister Narendra Modi announced that India would intensify its cooperation with Africa, and outlined ten guiding principles for deepening India's engagement on the African continent. These include, among others, developing cooperation based on the priorities of African countries, further removing barriers in trade with India, and using India's experience with the digital revolution to support Africa's development.

\section{Trends in China-Africa and India-Africa Merchandise Trade}

In the $21^{\text {st }}$ century, both China and India expanded their trade with Africa. Over the period from 2001 to 2017, China increased its merchandise trade with Africa 18 times, while India's trade increased 11.8 times. The value of the Asian giants' trade with Africa was growing exponentially up to 2008. In 2009, China's and India's bilateral trade in goods with Africa declined but during the next five years it increased nearly two times. 
In 2009, China became the second trading partner for Africa (after the European Union), and five years later India-Africa bilateral merchandise trade surpassed U.S.-Africa trade. Trade in goods between the Asian giants and Africa slowed down in the years 2015-2017 (Figure 1).
5.2 percent of Chinese total trade). Between 2008 and 2017, African countries experienced a 0.1 percent decrease in India's total trade and a 0.3 percent increase in China's trade.

The value of the Chinese exports of goods to Africa rose from $\$ 49.2$ bil-

Figure 1: Bilateral Trade in Goods of China and India with Africa (Current Prices, \$ Billion) ${ }^{9}$

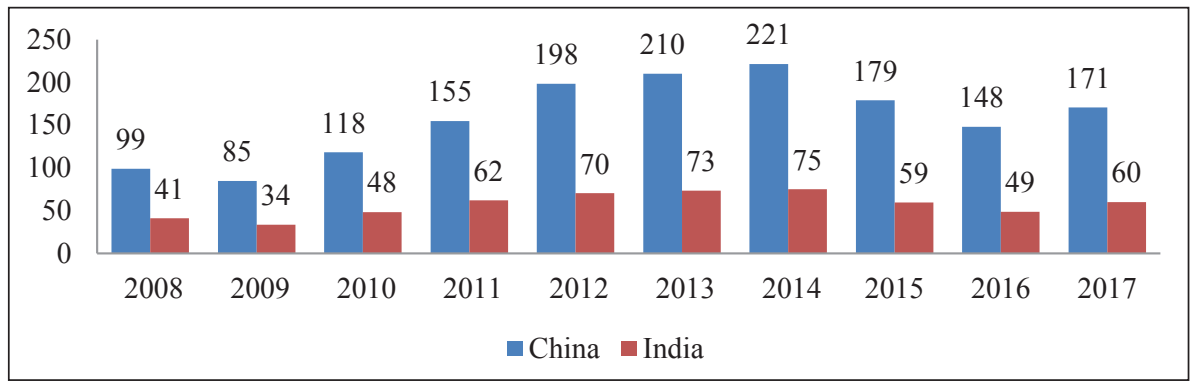

Between 2008 and 2017, China-Africa bilateral trade in goods grew at 9.8 percent annually while India-Africa grew at 7.1 percent. In the shorter period between 2013-2017, both China and India recorded negative growth rates of bilateral trade (Table 1). lion in 2008 to $\$ 107.7$ billion in 2015 and then declined to $\$ 93.3$ billion in 2017. China's imports of goods increased from $\$ 49.6$ billion in 2008 to $\$ 117.7$ billion in 2013 and then decreased to $\$ 79.2$ billion in 2017 . The average annual growth rate of China's exports to Africa was bigger than its

Table 1: Annual Growth Rates of China and India's Trade with Africa ${ }^{10}$

\begin{tabular}{|c|c|c|c|c|c|c|}
\hline \multirow[t]{2}{*}{ Years } & Exports & Imports & $\begin{array}{l}\text { Total } \\
\text { Trade }\end{array}$ & Exports & Imports & $\begin{array}{l}\text { Total } \\
\text { Trade }\end{array}$ \\
\hline & \multicolumn{3}{|c|}{ China } & \multicolumn{3}{|c|}{ India } \\
\hline 2008-2017 & $10.0 \%$ & $9.4 \%$ & $9.8 \%$ & $7.3 \%$ & $7.1 \%$ & $7.1 \%$ \\
\hline 2013-2017 & $1.8 \%$ & $-6.9 \%$ & $-2.8 \%$ & $-2.3 \%$ & $-3.6 \%$ & $-3.1 \%$ \\
\hline
\end{tabular}

Africa is a more strategic trading partner for India than it is for China as it accounted for 8.1 percent of India's trade with the world in 2017, while only 4.2 percent of China's total trade. The highest share of Africa in the Asian giants' trade was in 2014 (9.7 percent of Indian total trade and growth rate of imports. The growth rate of Chinese exports was also positive over the period 2013-2017 (Table 1). In the years 2009 and 2015-2017, China experienced a positive trade balance in merchandise trade with Africa (Figure 2). It is worth noting that over the period 2008-2017, the 
Figure 2: China's Trade with Africa (\$ Billion) ${ }^{11}$

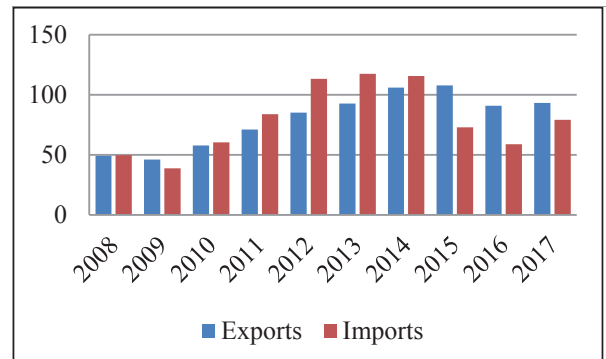

value of Chinese goods exported to Africa surpassed the value of goods imported by China from African countries by nearly $\$ 10$ billion. It seems that after the global crisis, Africa became more of an export than an import market for China.

Contrary to China, India experienced a negative trade balance with Africa in the whole analyzed period (Figure 3). The Indian exports to African countries rose from $\$ 14.9$ billion in 2008 to $\$ 24.4$ billion in 2017. The highest value of India's exports to Africa ( $\$ 34.6$ billion) was recorded in 2014. India imported significantly more goods from Africa than it exported there. The value of India's imports increased from \$26.1 billion in 2008 to $\$ 43$ billion in 2013 , and then declined to $\$ 35.8$ billion in
Figure 3: India's Trade with Africa (\$ Billion) ${ }^{12}$

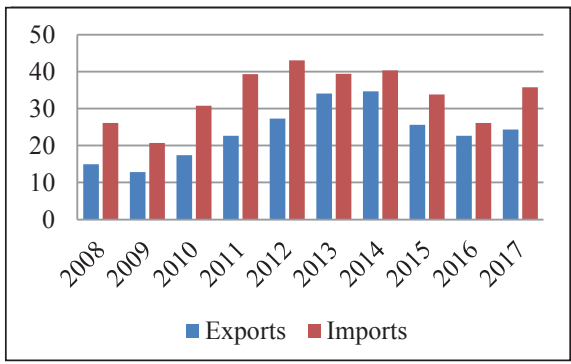

2017. Since the global crisis, India's exports to Africa have been growing a bit faster than its imports from the region (Table 1).

After 2008, China increased its advantage over India in trade with Africa. In the years 2008-2017, China-Africa trade was nearly triple of India-Africa trade. China's trade domination in Africa is more evident in the case of Africa's least developed countries. In the years from 2008 to 2017, the value of China's bilateral trade in goods with Africa's 33 LDCs surpassed India's by 4.2 times. Trends in bilateral merchandise trade with the least developed African countries are shown in Figure 4.

In recent years, China has gradually increased its advantage over India

Figure 4: Bilateral Trade in Goods of China and India with Africa's 33 LDCs (Current Prices, \$ Billion) $)^{13}$

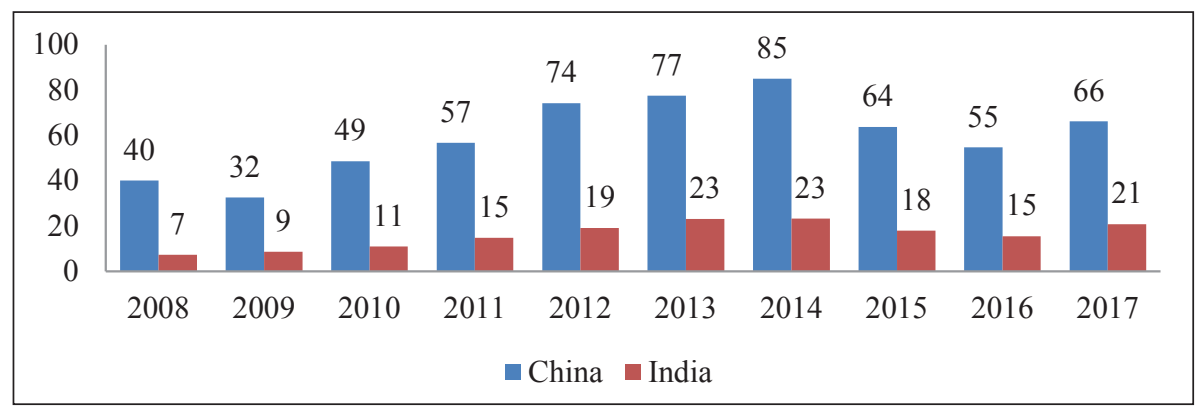


Figure 5: Exports of Goods to Africa ${ }^{14}$

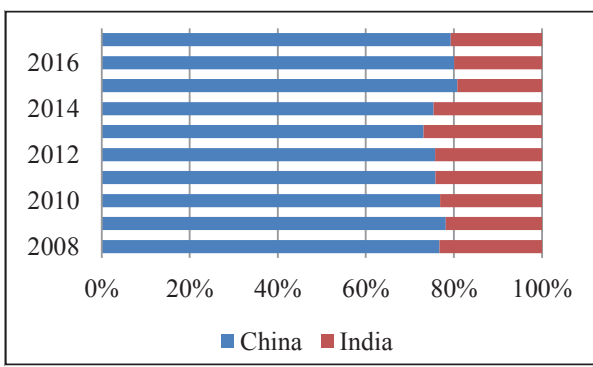

in exports of goods to Africa. From 2013 to 2017, India recorded a 6.2 percent decline in the African market. In 2013, imports of goods from China accounted for 73.1 percent and imports from India accounted for 26.9 percent of Africa's imports, while five years later the shares were 79.3 percent and 20.7 percent, respectively (Figure 5). In the years 20082017, the value of China's exports of goods to Africa was 3.4 times bigger than the Indian ones and three times bigger to Africa's LDCs. China has also become a more important destination market for African countries than India. In 2008, Africa exported 65.5 percent of its goods to China and 34.5 percent to India. Ten years later, the shares were 68.9 percent and 31.1 percent, respectively (Figure 6). In the years 2008-2017, the value of China's imports from Africa was 2.4 times bigger than India's and China's imports from Africa's LDCs surpassed India's by 4.5 times.

Over the period 2008-2017, India exported more goods than China only to four small African countries (Mauritius, Somalia, Swaziland, and Seychelles). In the years 2013-2017, India's exports in goods slightly surpassed those of China in Mauritius,
Figure 6: Imports of Goods from Africa ${ }^{15}$

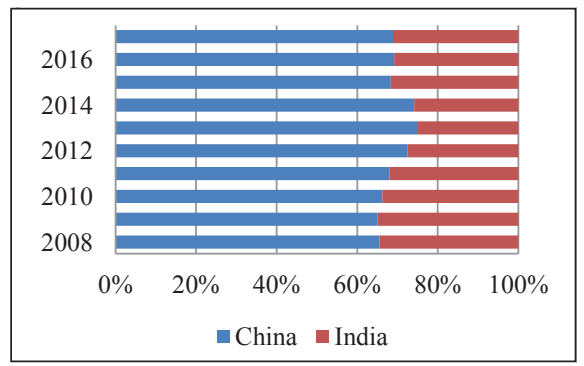

Somalia, Swaziland, and the Central African Republic. During the analyzed ten years, India was a more important destination market than China for 24 African countries. However, India had a significant advantage over China in imports of goods only from Nigeria. Indian imports surpassed those of China by more than $\$ 1$ billion only in Egypt, Morocco, Botswana, Côte d'Ivoire, Tanzania,

\section{Trade relations between China} and Africa, and India and Africa create and sustain the asymmetry between those Asian countries and the netwinner and net-loser African countries

Senegal, Guinea-Bissau, Ghana, and Guinea. In the case of the remaining 14 African countries, India's advantage over China in imports of goods was very small.

There are similarities between China-Africa and India-Africa trade in goods. In the years from 2008 to 
2017, imports of the top five African countries accounted for 51.1 percent of China's exports to the continent, while exports of the top five African countries accounted for nearly 76 percent of the Chinese imports from Africa. Correspondingly, 55.1 percent of India's exports in goods were directed to five African countries, while 74.4 percent of India's imports came from five African countries. Principally, China and India trade with ten African countries (Table 2). Compared to India, China has slightly diversified African markets for their goods. Both Asian countries intensified their imports from selected African suppliers.

According to the value of bilateral trade, in the years from 2008 to 2017, the most important of China's trad- ing partners were South Africa (25.9 percent of China-Africa total trade), Angola (16.6 percent), Nigeria (7.2 percent), Egypt (5.9 percent), and Algeria (4.4 percent). India traded mainly with Nigeria (22.9 percent of India-Africa total trade), South Africa (18.6 percent), Angola (8.7 percent), Egypt (7.3 percent), and Kenya (4.8 percent). The rankings of the top five African importers from the Asian giants, and African exporters to those countries are presented in Table 3.

In the years 2013-2017, China's main destination markets in Africa were South Africa (15.5 percent of China's exports to Africa), Nigeria (12.9 percent), Egypt (10.3 percent), Algeria (7.2 percent), and Kenya (5.0 percent). China imported goods first of

Table 2: The Share of Top Trading Partners in China's and India's Trade with Africa, 2008-2017 ${ }^{16}$

\begin{tabular}{|c|c|c|c|c|c|c|}
$\begin{array}{c}\text { Number of Top } \\
\text { Trading Partners }\end{array}$ & \multicolumn{3}{|c|}{$\begin{array}{c}\text { Exports } \\
\text { Imports }\end{array}$ Total Trade } & Exports & \multicolumn{3}{c|}{ Imports } & Total Trade \\
\hline Five & $51.1 \%$ & $75.9 \%$ & $59.9 \%$ & $55.1 \%$ & $74.4 \%$ & $62.3 \%$ \\
\hline Ten & $69.2 \%$ & $85.7 \%$ & $72.5 \%$ & $71.9 \%$ & $85.0 \%$ & $77.4 \%$ \\
\hline Twenty & $88.1 \%$ & $99.5 \%$ & $87.8 \%$ & $87.8 \%$ & $94.9 \%$ & $88.8 \%$ \\
\hline
\end{tabular}

Table 3: Top Five Trading Partners of China and India in Africa, 2008-2017 (\$ Billion) ${ }^{17}$

\begin{tabular}{|c|c|c|c|c|c|c|}
\hline \multirow[b]{2}{*}{ Rank } & \multicolumn{2}{|c|}{ Exports of Goods } & \multicolumn{2}{|l|}{ Imports of Goods } & \multicolumn{2}{|c|}{ Bilateral Trade } \\
\hline & $\begin{array}{l}\text { Trading } \\
\text { Partner }\end{array}$ & Value & Trading Partner & Value & $\begin{array}{l}\text { Trading } \\
\text { Partner }\end{array}$ & Value \\
\hline \multicolumn{7}{|c|}{ China } \\
\hline 1 & South Africa & 131.5 & South Africa & 279.3 & South Africa & 410.8 \\
\hline 2 & Nigeria & 100.4 & Angola & 232.1 & Angola & 263.9 \\
\hline 3 & Egypt & 83.2 & Congo & 37.9 & Nigeria & 113.8 \\
\hline 4 & Algeria & 57.3 & $\begin{array}{l}\text { Democratic Republic of } \\
\text { the Congo }\end{array}$ & 25.5 & Egypt & 94.0 \\
\hline 5 & Ghana & 36.0 & Libya & 24.1 & Algeria & 69.5 \\
\hline \multicolumn{7}{|c|}{ India } \\
\hline 1 & South Africa & 40.0 & Nigeria & 109.0 & Nigeria & 131.1 \\
\hline 2 & Kenya & 26.6 & South Africa & 66.4 & South Africa & 106.4 \\
\hline 3 & Egypt & 22.8 & Angola & 45.3 & Angola & 49.7 \\
\hline 4 & Nigeria & 22.1 & Egypt & 18.7 & Egypt & 41.5 \\
\hline 5 & Tanzania & 18.8 & Algeria & 10.3 & Kenya & 27.7 \\
\hline
\end{tabular}


all from South Africa (38.2 percent of China's imports from Africa), Angola (25.6 percent), Congo (4.5 percent), the Democratic Republic of the Congo (3.1 percent), and Zambia (3.0 percent). India's major export markets in Africa were South Africa (16.0 percent of India's exports to Africa), Kenya (11.2 percent), Egypt (9.1 percent), Tanzania (8.8 percent), and Nigeria (8.4 percent). India primarily imported good from Nigeria (31.6 percent of India's imports from Africa), South Africa (18 percent), Angola (12.4 percent), Ghana (4.8 percent), and Egypt (4.6 percent).

Trade relations between China and Africa, and India and Africa create and sustain the asymmetry between those Asian countries and the net-winner and net-loser African countries. In the years 2008-2017, China had a trade deficit with 17 African countries. The biggest trade deficit China recorded was in trade with Angola, South Africa, and Congo. India imported more goods from 22 countries in the region than it exported. India's imports exceeded its exports most notably in Nigeria, Angola, and South Africa.

In recent years, China has substantially increased its importance as a source of imports for African countries. In the years 2015-2017, China was the largest import market for Kenya, Sudan, Togo, Tanzania, South Africa, Uganda, Cameroon, Egypt, Ethiopia, Rwanda, Ghana, Burundi, Burkina Faso, Angola, Algeria, and Guinea and the second largest for Mauritius, Mali, Senegal, Nigeria, Niger, and Malawi. India was the largest import market only for Mauritius and Benin but the second largest import market for Tanzania, Uganda, Kenya, and Burundi. The shares of imports in goods from the Asian giants in the African countries' total imports are presented in Table 4.

Table 4: Imports from China and India as a Percent of African Countries' Total Imports ${ }^{18}$

\begin{tabular}{|c|c|c|c|c|c|}
\hline Country & Year & $\begin{array}{l}\text { Percent of } \\
\text { Country's } \\
\text { Imports }\end{array}$ & Country & Year & $\begin{array}{l}\text { Percent of } \\
\text { Country's } \\
\text { Imports }\end{array}$ \\
\hline \multicolumn{6}{|c|}{ Imports from China } \\
\hline Kenya & 2017 & $22.6 \%$ & Senegal & 2017 & $7.2 \%$ \\
\hline Sudan & 2017 & $22.0 \%$ & Ethiopia & 2016 & $31.9 \%$ \\
\hline Togo & 2017 & $19.6 \%$ & Rwanda & 2016 & $21.2 \%$ \\
\hline Tanzania & 2017 & $19.4 \%$ & Nigeria & 2016 & $19.7 \%$ \\
\hline South Africa & 2017 & $19.3 \%$ & Niger & 2016 & $16.2 \%$ \\
\hline Uganda & 2017 & $17.6 \%$ & Burkina Faso & 2016 & $14.5 \%$ \\
\hline Cameroon & 2017 & $17.2 \%$ & Angola & 2015 & $16.9 \%$ \\
\hline Mauritius & 2017 & $16.4 \%$ & Algeria & 2015 & $15.9 \%$ \\
\hline Mali & 2017 & $15.2 \%$ & Guinea & 2015 & $14.9 \%$ \\
\hline Egypt & 2017 & $12.2 \%$ & Malawi & 2015 & $13.1 \%$ \\
\hline \multicolumn{6}{|c|}{ Imports from India } \\
\hline Mauritius & 2017 & $16.4 \%$ & Kenya & 2017 & $9.9 \%$ \\
\hline Tanzania & 2017 & $15.0 \%$ & Benin & 2016 & $14.9 \%$ \\
\hline Uganda & 2017 & $13.2 \%$ & Burundi & 2016 & $14.1 \%$ \\
\hline
\end{tabular}


Table 5: Exports to China and India as a Percent of African Countries' Total Exports $^{19}$

\begin{tabular}{|c|c|c|c|c|c|}
\hline Country & Year & $\begin{array}{c}\text { Percent of } \\
\text { Country's } \\
\text { Exports }\end{array}$ & Country & Year & $\begin{array}{c}\text { Percent of } \\
\text { Country's } \\
\text { Exports }\end{array}$ \\
\hline Mauritania & 2017 & $\begin{array}{c}\text { Exports to China } \\
\text { Ex.1\% }\end{array}$ & Zambia & 2017 & $16.3 \%$ \\
\hline Congo & 2017 & $33.9 \%$ & South Africa & 2017 & $9.8 \%$ \\
\hline Sudan & 2017 & $17.3 \%$ & Angola & 2015 & $43.2 \%$ \\
\hline \multicolumn{7}{|c|}{$\begin{array}{c}\text { Exports to India } \\
\text { Tanzania }\end{array}$} & 2017 & $23.5 \%$ & Botswana & 2016 & $15.1 \%$ \\
\hline Cameroon & 2017 & $12.1 \%$ & Ghana & 2016 & $14.6 \%$ \\
\hline Nigeria & 2016 & $18.0 \%$ & Guinea & 2015 & $16.4 \%$ \\
\hline Benin & 2016 & $15.4 \%$ & Angola & 2015 & $8.1 \%$ \\
\hline
\end{tabular}

Several African countries are dependent on Asian giants in trade. In 2017, China absorbed 35.1 percent of Mauritania's exports of goods and 33.9 percent of Congo's. China was also the largest export market for Angola, South Africa, and the second largest export market for Sudan and Zambia. In 2015, 43.2 percent of Angola's exports were directed to China. India was the largest export market for Tanzania, Nigeria, and Benin, and the second largest export market for Cameroon, Botswana, Ghana, Guinea, and Angola. The shares of exports in goods to China and India in the African countries' total exports are presented in Table 5.

Both China and India primarily import mineral resources and raw materials from Africa. China supplies industrial machinery, electrical and electronic equipment, transport equipment, and textiles and clothing to African countries. India exports distillation products, automobiles, textiles, and pharmaceuticals to the region.

Trade exchange with China benefits African countries; however, it makes them more and more dependent on the condition of the Chinese economy. Besides, the expansion of Chinese goods causes the displacement of African products from local markets. Compared to Chinese, Indian exports cause less damage to African markets because India exports to Africa not only final goods but also components of production.

\section{Conclusion}

Since the 2008 financial crisis, China has been gradually increasing its advantage over India in merchandise trade with Africa. In the years 20082017, the value of China's bilateral trade with all African countries surpassed India's nearly three times, while Chinese merchandise trade with Africa's 33 LDCs was over four times bigger than Indian trade. India dominated China in bilateral trade with only eight African countries. After the global crisis, Africa became more of an export than an import market for China. Contrary to China, India recorded a negative trade balance with Africa.

Both China and India work to increase their trade in goods with 
Africa by intensively developing South-South cooperation with African countries. The Asian giants also develop and strengthen their trade relations during high-level visits and official forums such as the Forum on China-Africa Cooperation or the India-Africa Forum. Both China and India use foreign aid in the form of loans and grants to develop bilateral trade relations with African countries. Compared to India, China is diplomatically more active and invests more in Africa. Moreover, it supports domestic companies which trade with African countries more intensively than India does, and provides more development assistance to the region.

Undoubtedly, trade exchange with China and India benefits African countries. However, it seems that Africa, like Latin America before, will soon become more of a destination market for Chinese goods than a source of natural resources for China's economy, therefore African products will have to compete with Chinese products not only in international but first in local markets.

\section{Endnotes}

1. Emmanuel Obuah, "Trade between China and Africa: Trends, Changes, and Challenges," International Journal of China Marketing, Vol. 2, No. 2 (2012), p. 75.

2. Wioletta Nowak, "China-Africa and India-Africa Trade in the Years 2000-2014," Procedia Economics and Finance, Vol. 39 (2016), pp. 141-142.

3. Wioletta Nowak, "North-South Trade Competition in Africa's Least Developed Countries," International Business and Global Economy, Vol. 35, No. 1 (2016), p. 225.
4. Burkina Faso, Gambia, Rwanda, and São Tomé and Príncipe are excluded from China's DFQF programme. Equatorial Guinea still benefits from the program despite the fact that it graduated from the LDC category in 2017.

5. "Preferential Trade Arrangements: Duty-free Treatment for LDCs - China," WTO, (2018), retrieved from http://ptadb.wto.org/ptaBeneficiaries.aspx.

6. "Handbook on India's Duty-Free Tariff Preference Scheme for Least Developed Countries," UNCTAD, (2017), retrieved from https://unctad. org/en/PublicationsLibrary/itcdtsbmisc77_ en.pdf.

7. The following African countries are beneficiaries from the DFTP scheme: Benin, Burkina Faso, Burundi, Chad, Comoros, Central African Republic, Eritrea, Ethiopia, Gambia, Guinea, Guinea-Bissau, Lesotho, Liberia, Madagascar, Malawi, Mali, Mozambique, Niger, Rwanda, Senegal, Somalia, Sudan, Uganda, Tanzania, Togo, and Zambia.

8. "Handbook on India's Duty-Free Tariff Preference Scheme for Least Developed Countries," UNCTAD, (2017), retrieved from https://unctad. org/en/PublicationsLibrary/itcdtsbmisc77_ en.pdf.

9. Own calculations based on UN Comtrade Database, retrieved from http://comtrade.un.org/ data/.

10. Own calculations based on UN Comtrade Database.

11. Own calculations based on UN Comtrade Database.

12. Own calculations based on UN Comtrade Database.

13. Own calculations based on UN Comtrade Database.

14. Own calculations based on UN Comtrade Database.

15. Own calculations based on UN Comtrade Database.

16. Own calculations based on UN Comtrade Database.

17. Own calculations based on UN Comtrade Database.

18. UN Comtrade Database, retrieved from http:// comtrade.un.org/data/.

19. UN Comtrade Database. 